УДК 343.232-048.445(477:438)

DOI https://doi.org/10.32849/2663-5313/2020.2.49

Володимир Лутчин,

аспірант кафедри кримінального права та кримінологіі

Львівського національного університету імені Івана Франка

\title{
КРИТЕРІЇ КЛАСИФІКАЦІЇ КРИМІНАЛЬНИХ ПРАВОПОРУШЕНЬ НА ЗЛОЧИНИ ТА КРИМІНАЛЬНІ ПРОСТУПКИ У КРИМІНАЛЬНОМУ ПРАВІ УКРАЇНИ ТА РЕСПУБЛІКИ ПОЛЬЩА
}

Стаття присвячена дослідженню критеріїв класифікачї кримінальних правопорушень на злочини та кримінальні проступки в кримінальному праві України та Республіки Польща. У рамках дослідження розглянуто формальний $і$ матеріальний критерії поділу кримінальних правопорушень, які виділяються як українськими, так і польськими науковиями. Формальний критерій поділу у кримінальному праві Республіки Польща зумовлюється певними елементами, такими як юридичний наслідок і умова, яка передбачена кримінальним законом. Що стосується юридичного наслідку, то у иьому разі йдеться про вид і міру покарання, передбачені у санкції відповідної кримінально-правової норми. Під законодавчою умовою розуміється форма вини, оскільки відповідно до артикля 8 Кримінального кодексу Республіки Польща злочин може бути вчинений лише умисно, а кримінальний проступок як умисно, так і необережно. Що стосується украйнського кримінального права, то формальний критерій поділу кримінального правопорушення складається лише з юридичного наслідку, тобто йдеться про вид і міру покарання, передбачені у санкиї̈ відповідної кримінально-правової норми. Такий висновок був зроблений завдяки дослідженню нової редакиії статті 12 Кримінального кодексу України, яка пропонується Законом України «Про внесення змін до деяких законодавчих актів України щодо спрощення досудового розслідування окремих категорій кримінальних правопорушень» від 22.11.2018 p. № 2617-VIII, набрання чинності якого заплановане на1 липня 2020 року.

Що стосується матеріального критерію, то він полягає в поділі кримінальних правопорушень на злочини і кримінальні проступки залежно від тяжкості кримінального правопорушення, що визначається за допомогою ступеня суспільної небезпеки (икідливості) діяння. Однак у кримінально-правовій доктрині як України, так і Республіки Польща немає єдиного підходу шодо тлумачення иих термінів, тому запропоновані позииї є актуальним для обох держав.

Досліджено також обставини й ознаки, що впливають на тяжкість кримінального правопорушення як в Україні, так і Республічі Польща.

Ключові слова: формальний критерій, матеріальний критерій, ступінь суспільної небезпеки (шкідливості) діяння, тяжкість кримінального правопорушення, санкція, кримінальнопротиправне діяння.

Постановка проблеми. У зв'язку із прийняттям Верховною Радою України Закону України «Про внесення змін до деяких законодавчих актів України щодо спрощення досудового розслідування окремих категорій кримінальних правопорушень» від 22.11.2018 р. № 2617-VIII, набуття чинності якого заплановане на 1 липня 2020 року, котрий запроваджує інститут кримінальних правопорушень і його поділ на злочини і кримінальні проступки, виникає необхідність у дослідженні критеріїв, які використовуються законодавцем у разі такого поділу. Що стосується кримінального права Республіки Польща, то інститут кримінальних правопорушень і його поділ на злочини та кримінальні проступки закріплений у чинному Кримінальному кодексі (далі - КК) Республіки Польща, який був прийнятий у 1997 року. Тому дослідження польських доктринальних i законодавчих позицій з цього приводу допоможе нам краще зрозуміти природу поділу кримінальних правопорушень, запропонованих українським законодавцем.

Аналіз останніх досліджень і публікацій. Над дослідженням критеріїв класифікації кримінально-протиправних діянь працювали такі вчені, як: Л. Гардоцький, А. Грешков'як, К. Бучала, А. Золл, Л.Н. Кривоченко, М.I. Хавронюк та інші. Однак дослідження здійснювалось у межах кримінальноправової системи однієї держави.

Мета статті. Основним завданням цієї наукової статті є дослідження критеріїв поділу 
кримінальних правопорушень у межах кримінально-правових систем України ॥ і Республіки Польща.

Виклад основного матеріалу. Під час класифікації кримінальних правопорушень на злочини і кримінальні проступки варто керуватися двома критеріями: формальним і матеріальним [1, с. 58]. Ці критерії були запропоновані ще Л. Кривоченком і залишаються актуальними для поділу кримінальних правопорушень у наш час, і не лише для кримінального права України, а й Республіки Польща, оскільки формальний і матеріальний критерії поділу кримінальних правопорушень запропонований у коментарі до КК Республіки Польща, авторами якого є К. Бучала і А. Золл [7, с. 81].

Так, за формальним критерієм віднесення кримінально-протиправного діяння до злочинів чи кримінальних проступків зумовлюється певними юридичними наслідками за його вчинення і умовами, які передбачені кримінальним законом. Що стосується матеріального критерію, то він полягає в поділі кримінальних правопорушень на злочини і кримінальні проступки за тяжкістю кримінального правопорушення (waga przestępstwa).

Насамперед нами розглянуто формальний критерій класифікації кримінальних правопорушень, який передбачений у КК Республіка Польща, з подальшим його аналізом і порівнянням з критерієм, передбаченим у Законі України «Про внесення змін до деяких законодавчих актів України щодо спрощення досудового розслідування окремих категорій кримінальних правопорушень» від 22.11 .2018 р. № 2617-VIII, котрий передбачає імплементацію інституту кримінальних правопорушень і його поділу на кримінальні проступки і злочини у КК України.

У кримінальному праві Республіки Польща формальний критерій поділу кримінальних правопорушень складається з двох елементів: юридичних наслідків, передбачених за кримінально-протиправне діяння, іумов, якіпередбаченікримінальнимзаконом.

Що стосується юридичних наслідків, то у цьому разі йдеться про вид і міру покарання, передбачені у санкції відповідної кримінальної норми.

Правила поділу кримінальних правопорушень залежно від виду і міри покарання передбачені у арт. 7 КК Республіки Польща. Відповідно до нього злочин (zbrodnią) - це кримінально-протиправне діяння, що карається позбавленням волі на строк не менше трьох років або більш суворим покаранням (арт. 7 § 2 КК Республіки Польща). Законо- давець у цьому разі визначає нижню межу, яка має бути не менше три роки. Такого правила, яке застосовує законодавець до злочину, було б досить для класифікації кримінальних правопорушень на злочини i кримінальні проступки. Однак, окрім цього, у арт. 7 § 3 КК Республіки Польща визначено, які діяння є кримінальними проступками з метою відмежування їх від адміністративних правопорушень (wykroczeń) $[14$, с. 283]. Кримінальним проступком (występkiem) є кримінально-протиправне діяння, що карається штрафом понад тридцять денних станок або більше п’яти тисяч злотих, обмеженням волі понад один місяць або позбавлення волі, що перевищує один місяць. Заборонені діяння, за яких верхня межа покарання не перевищує таких границь, визначаються адміністративними правопорушеннями, таким викладом кримінальноправової норми законодавець у арт. 7 § 3 КК Республіки Польща визначив верхню межу виду і строків покарання адміністративного правопорушення. Це має велике значення, оскільки КК Республіки Польща містить кримінальні правопорушення, подібні за своїм змістом до адміністративних правопорушень [8, с. 62]. Основною відмінністю $€$ також те, що адміністративні правопорушення не пов'язані зі значним моральним осудом, який характерний для більшості кримінальних правопорушень, і відповідальність за них передбачена Кодексом адміністративних правопорушень Республіки Польща (Kodeks wykroczeń) [11, с. 10].

Що стосується законодавчої умови, яка виступає другим обов'язковим елементом формального критерію поділу кримінальних правопорушень на злочини і кримінальні проступки, то вона закріплена у арт. 8 КК Республіки Польща і зумовлена формою вини, a саме тим, що злочином може бути лише умисне кримінально-протиправне діяння, що стосується кримінального проступку, то ним може бути як умисне, так і необережне кримінально-протиправне діяння. Якщо кримінальне правопорушення вчинено 3 необережною формою вини, то у цьому разі завжди йтиметься про кримінальний проступок, виходячи 3 положень вищезазначеної кримінально-правової норми. Тому правила щодо поділу кримінальних правопорушень на злочини і кримінальні поступки, передбачені в арт. 7 КК Республіки Польща, застосовуються лише у разі поділу умисних кримінально-протиправних діянь.

Формальним критерієм поділу кримінальних правопорушень на злочини і кримінальні проступки у КК Республіки Польща служить вид і міра покарання, а також форма 
вини. 3 цього випливає, що до групи злочинів належать умисні, кримінально-протиправні діяння, за які передбачено покарання у вигляді позбавлення волі від трьох років або більш суворе покарання, під яким розуміється позбавлення волі на двадцять п'ять років або довічне позбавлення волі, виходячи з видів покарань, передбачених в арт. 32 КК Республіки Польща. Що стосується групи кримінальних проступків, то до них належать умисні і необережні кримінальнопротиправні діяння, за які передбачено покарання у вигляді штрафу понад тридцять денних станок або більше п'яти тисяч злотих, обмеженням волі понад один місяць або позбавлення волі в межах понад один місяць і до трьох років.

Що стосується кримінального права України, то формальний критерій поділу кримінальних правопорушень складається лише $з$ юридичних наслідків, передбачених за кримінально-протиправне діяння. У цьому разі йдеться про вид і міру покарання, передбачену законодавцем для певного кримінального правопорушення. Такий критерій випливає із положень Закону України «Про внесення змін до деяких законодавчих актів України щодо спрощення досудового розслідування окремих категорій кримінальних правопорушень» від 22.11.2018 р. № 2617-VIII, який пропонує нову редакцію ст. 12 КК України, а саме передбачає у частині першій поділ кримінальних правопорушень на кримінальні проступки і злочини. У частині 2 статті 12 КК України нової редакції законодавець закріпив поняття «кримінальний проступок», під яким розуміється передбачене КК України діяння (дія чи бездіяльність), за вчинення якого передбачено основне покарання у вигляді штрафу не більше трьох тисяч неоподатковуваних мінімумів доходів громадян або інше покарання, не пов'язане 3 позбавленням волі [3]. Цього визначення досить для поділу кримінальних правопорушень.

3 його аналізу можна зробити висновок, що до групи кримінальних проступків належать кримінально-протиправні діяння, за вчинення яких передбачено основне покарання у вигляді штрафу не більше трьох тисяч неоподатковуваних мінімумів доходів громадян або громадські роботи, виправні роботи, службове обмеження для військовослужбовців, позбавлення права обіймати певні посади або займатись певною діяльністю, арешт, обмеження волі, тримання в дисциплінарному батальйоні військовослужбовців незалежно від їх строку. До групи злочинів належать кримінально-протиправні діяння, за вчинення яких передбачено основне покарання у вигляді штрафу понад три тисячі неоподатковуваних мінімумів доходів громадян, позбавлення волі або довічне позбавлення волі. У такому разі законодавець для формального критерію вибрав лише основні види покарань, які враховуються під час визначення групи кримінального правопорушення. Перелік видів покарань, які належать до основних, закріплений у ст. 52 КК України.

Переходячи до матеріального критерію поділу кримінальних правопорушень, варто зазначити, що він є спільним і покладений в основу поділу кримінальних правопорушень як у кримінальному праві Республіки Польща, так і України. У цьому разі йдеться про тяжкість кримінального правопорушення, що визначається за допомогою ступеня суспільної небезпеки (шкідливості) діяння [10, с. 39-40 ;7, с. 81]. Однак у кримінально-правовій доктрині як України, так і Республіки Польща немає єдиного підходу до тлумачення цих понять.

Так, Апеляційний суд у Катовіце зазначає у своєму вироку, що ступінь суспільної шкідливості діяння - це іманентна (внутрішня) ознака діяння, яка дає змогу розрізнити діяння тривіальні (легковажні) від серйозних i визнавати кримінальними правопорушеннями лише ті, які фактично і реально завдають шкоди конкретному благу особи чи суспільному благу. Ця змінна ознака діяння, котра формально вбирає в себе всі ознаки конкретного виду забороненого діяння, підлягає індивідуальній градації залежно від конкретних об'єктивних і суб'єктивних обставин, може бути: малозначна (znikoma), незначна (nieznaczna), висока (wysoka) чи особливо висока (szczeg lnie wysoka) [16]. Натомість, КК Республіки Польща використовує поняття «значна» (znaczna) і «малозначна» (znikoma) суспільна шкідливість діяння. Однак арт. 66 § 1 КК Республіки Польща, у якій законодавець закріпив можливість суду призначити умовне покарання, якщо ступінь суспільної шкідливості діяння не $є$ значним. Завдяки такому законодавчому формулюванню кримінально-правової норми виникла певна дискусія у науковій спільноті з приводу того, чи слід ототожнювати ступінь суспільної шкідливості діяння, який «не є значним» і «незначний». Крапка у цій дискусії була поставлена рішенням Апеляційного суду в місті Кракові, у якому зазначається, що ступінь суспільної небезпеки, який «не є значним», не слід ототожнювати 3 «незначним» [15]. У цьому разі суд виділив новий ступінь суспільної шкідливості діяння як «середній», який існує між «незначним» $\mathrm{i}$ «значним». Тому суд може застосо- 
вувати положення арт. 66 § 1 КК Республіки Польща у тому разі, коли ступінь суспільної шкідливості діяння є «незначним» або «середнім». Таке судове рішення вплинуло і на кримінально-правову доктрину Республіки Польща, оскільки науковці стали виділяти ще один ступінь суспільної шкідливості діяння. Пропонується шестибальна шкала, за якою можна оцінювати суспільну шкідливість діяння, яка включає такі ступені: малозначний, незначний, середній, значний, високий, дуже високий [4, с. 91].

Виходячи 3 положень КК Республіки Польща, ступінь суспільної шкідливості не лише визначає тяжкість кримінального правопорушення, але й становить матеріальну основу кримінального правопорушення. Оскільки відповідно до арт. 1 § 2 КК Республіки Польща не $є$ кримінальним правопорушенням заборонене законом діяння, ступінь суспільної шкідливості якого є малозначним. Р. Гурал зазначає, що малозначний ступінь суспільної шкідливості діяння є близький до нуля [9, с. 14]. 3 цього випливає, що для кримінального права Республіки Польща мають значення лише діяння, ступінь суспільної шкідливості яких є більшим, ніж малозначний. Проте діяння з малозначним ступенем суспільної шкідливості підпадають під дію Кодексу адміністративних правопорушень Республіки Польща (Kodeks wykroczeń). Відповідно до арт. 1 § 1 цього Кодексу адміністративне правопорушення $є$ суспільно шкідливим діянням. Тому можна констатувати, що адміністративними правопорушеннями є протиправні діяння, ступінь суспільної шкідливості яких є малозначним [6, с. 88].

Також слід наголосити на тому, що ступінь суспільної небезпеки (шкідливості) діяння, визначений законодавцем, носить абстрактний характер, а оцінка ступеня суспільної небезпеки (шкідливості) діяння, яка здійснюється судом у межах судового розгляду, завжди є конкретною, оскільки стосується конкретного діяння [4, с. 88]. У цьому разі йдеться про те, що законодавець закріплює загальний ступінь суспільної небезпеки для певного виду кримінально-протиправних діянь. Що ж стосується суду, то він визначає індивідуальний ступінь суспільної небезпеки конкретного кримінально-протиправного діяння.

Що стосується тяжкості кримінального правопорушення, то Верховний суд Республіки Польща у своїй Постанові від 13 жовтня 2004 p. V KK 216/04 зазначив, що «тяжкість кримінального правопорушення» - це оціночне формулювання, тлумачення та застосування на практиці якого законодавець залишив для судових рішень та доктрини
[13]. 3 цього випливає, що поняття тяжкості кримінального правопорушення в доктрині і судовій практиці є малодослідженим і йому приділяється набагато менше уваги, ніж ступеню суспільної шкідливості діяння.

Повертаючись до кримінально-правової доктрини України, слід наголосити на тому, що тяжкість кримінального правопорушення $\epsilon$ новим поняттям для кримінального права України. Оскільки імплементація інституту кримінального правопорушення відбудеться 01 липня 2020 року внаслідок набуття чинності Законом України «Про внесення змін до деяких законодавчих актів України щодо спрощення досудового розслідування окремих категорій кримінальних правопорушень» від 22.11.2018 р. № 2617-VIII [3]. Тому в науковій доктрині ще немає розроблених концепцій з приводу матеріального критерію поділу кримінальних правопорушень.

Виходячи з вищевикладених позицій, на нашу думку, ступінь суспільної небезпеки (шкідливості) діяння - це його іманентна (внутрішня) ознака, яка формально вбирає в себе всі ознаки конкретного виду забороненого діяння, окреслює інтенсивність, з якою завдається негативний вплив на певний об'єкт, який перебуває під кримінально-правовою охороною.

А тяжкість кримінального правопорушення - це якісний критерій, який відображає суспільну небезпеку (шкідливість) певного виду кримінального правопорушення і визначається через законодавче відображення ступеня суспільної небезпеки (шкідливості) конкретного виду кримінальнопротиправного діяння. Так, український i польський законодавці передбачили дві групи тяжкості кримінального правопорушення: кримінальні проступки і злочини. Відповідну групу становлять кримінальнопротиправні діяння однакової тяжкості, із однаковими кримінально-правовими наслідками, які відповідають їхній тяжкості.

Враховуючи те, що тяжкість кримінального правопорушення - це якісний критерій, який відображає суспільну небезпеку (шкідливість) кримінально-протравного діяння, а ступінь суспільної небезпеки (шкідливість) діяння - це кількісний критерій, кримінальне право має бути підпорядковане філософському закону про взаємний перехід кількісних і якісних змін. Це значить, що у разі досягнення необхідної межі кількісного критерію можливий перехід до нової якості.

У межах кримінального права України та Республіки Польща перетворення кількісних змін на якісні здійснюється шляхом переходу за певних умов (кваліфікуючих ознак) кримінального правопорушення 
одного виду, з однієї групи кримінального правопорушення в іншу завдяки досягненню необхідного ступеня суспільної небезпеки (шкідливості) діяння.

3 урахуванням положень Закону України «Про внесення змін до деяких законодавчих актів України щодо спрощення досудового розслідування окремих категорій кримінальних правопорушень» від 22.11 .2018 р. № 2617-VIII [3] і чинного КК України [2] можна розглянути такі наглядні приклади такого перетворення

Так, кримінально-протиправне діяння, передбачене ч. 1 ст. 296 КК України (хуліганство), належить до групи кримінальних проступків, оскільки за нього передбачене покарання у вигляді штрафу від однієї тисячі до двох тисяч неоподатковуваних мінімумів доходів громадян або арешту на строк до шести місяців, або обмеження волі на строк до п'яти років. Проте те саме кримінальнопротиправне діяння, вчинене групою осіб, кримінальна відповідальність за яке передбачена ч. 2 ст. 296 КК України, належить до групи злочинів, оскільки законодавець збільшує санкцію, в якій передбачає покарання у вигляді обмеження волі на строк до п'яти років або позбавлення волі на строк до чотирьох років. У цьому разі змінюється тяжкість кримінального правопорушення, відбувається перехід кримінально-протиправного діяння одного виду з групи кримінальних проступків до групи злочинів завдяки досягненню необхідного ступеня суспільної небезпеки кримінально-протиправного діяння.

3 аналізу чинного КК України з урахуванням положень і змін, запропонованих вищезгаданим Законом України, нам вдалося виокремити й інші кримінальні правопорушення одного виду, в яких відбувається такий перехід, і які саме кваліфікуючі ознаки впливають на ступінь суспільної небезпеки діяння і на тяжкість кримінального правопорушення: форма співучасті (ст.ст. 126, 296, 185, 188-1, 190, 197-1, 206, 216, 239-1, 239-2, $248,280,296,302,310,311,355,358,400-1$ КК України); потерпілий (ст.ст. 144, 150, 163, 172, 342 КК України); суспільно небезпечні наслідки (ст.ст. 139, 150, 175, 182, 188-1, 190, 205, 206, 239-1, 252, 253, 271, 272, 275, 276, $279,281,282,283,311,350,355,357,371,381$, 412 КК України); предмет кримінального правопорушення (ст.ст. 268, 298-1, 357 КК України); повторність (ст.ст. 172, 182, 185, 188-1, 190, 205, 206, 216, 239-1, 239-2, 280, 311, 319, 323, 355, 358, 400-1 КК України); сукупність (ст.ст. 310, 323 КК України); рецидив (ст.ст. 197-1, 213, 248, 249, 302, 310 КК України); спосіб вчинення (ст.ст. 126, 154, 162, 248, 249, 252, 384 КК України); засоби і знаряддя (ст.ст. 163, 248, 353 КК України); місце (ст.ст. 197-1, 299 КК України); суб'єкт кримінального правопорушення (ст.ст. 129, 159, 162, 163, 248, 323 КК України); мета (ст.ст. 126, 302, 310, 311 КК України); мотив (ст.ст.126, 129, 371, 384 КК України); військовий стан (ст. 435 КК України).

У наведених нами вище кримінальних правопорушеннях відбувається перетворення кількісних показників на якісні, однак таке перетворення не завжди відбувається. Наприклад, можна розглянути ст. $286^{1}$ (керування транспортними засобами в стані алкогольного, наркотичного чи іншого сп'яніння або під впливом лікарських препаратів, що знижують увагу та швидкість реакції), якою відповідно до Закону України «Про внесення змін до деяких законодавчих актів України щодо спрощення досудового розслідування окремих категорій кримінальних правопорушень» від 22.11.2018 р. № 2617VIII планується доповнити КК України. Кваліфікуючий склад такого кримінального правопорушення (за ознакою повторності) передбачений ч. 2 ст. $286^{1}$, санкція якої містить покарання у вигляді штрафу до трьох тисяч неоподатковуваних мінімумів доходів громадян $з$ позбавленням права керувати транспортним засобом на строк від двох до трьох років. 3 чого можна зробити висновок, що законодавець не змінює тяжкість кримінального правопорушення, а відповідно, кримінально-протиправне діяння залишається в межах групи кримінальних проступків, аналогічно, як і основний склад, передбачений ч. 1 ст. $286^{1}$, за який передбачене покарання у вигляді штрафу від однієї тисячі до двох тисяч неоподатковуваних мінімумів доходів громадян з позбавленням права керувати транспортним засобом на строк до трьох років, який також належить до групи кримінальних проступків. У цьому разі основний і кваліфікований склад вище розглянутого кримінального правопорушення лишається в межах однієї групи кримінального правопорушення, а отже, тяжкість кримінального правопорушення залишається незмінною. Однак присутній законодавчо змінений ступінь суспільної небезпеки діяння, який збільшується за допомогою санкції кримінально-правової норми на тисячу неоподатковуваних мінімумів доходів громадян. Перехід кількісної категорії в якісну не відбувається у зв'язку 3 недосягненням необхідного кількісного показника. Аналогічна ситуація притаманна таким кримінальним правопорушенням з урахуванням положень КК України і вищезазначеного Закону України:статті 125, 164,165,171,173,184,192,205-1, 286-1, 337, 343, 351, 387, 389, 397 КК України. 
3 цього можна зробити висновок, що 3 набуттям чинності вищезгаданого Закону України законодавець передбачив два типи кримінальних правопорушень: змішані i самостійні. Змішаним є кримінальне правопорушення одного виду, основний склад якого є кримінальним проступком, а кваліфікований (у випадках наявності і особливо кваліфікований) склад є злочином. Самостійним $є$ кримінальне правопорушення одного виду, в якому основний і кваліфікований (у випадках наявності і особливо кваліфікований) склад $є$ кримінальним проступком або злочином.

Варто зазначити, що тяжкість самостійного кримінального правопорушення охоплюється певними ознаками. Основною ознакою тяжкості самостійного кримінального правопорушення є цінність об'єкта кримінально-протиправного посягання. Однак завдяки аналізу положень Закону України «Про внесення змін до деяких законодавчих актів України щодо спрощення досудового розслідування окремих категорій кримінальних правопорушень» від 22.11.2018 р. № 2617-VIII і чинного кримінального закону України нам вдалося виокремити й інші ознаки тяжкості кримінального правопорушення, в яких об'єкт кримінально-протиправного посягання спільний, але вони належать до різних груп кримінального правопорушення.

Перш за все такою ознакою є суспільно небезпечний наслідок. До прикладу можна розглянути кримінально-протиправне діяння, передбачене ст. 125 КК України (умисне легке тілесне ушкодження), основний і кваліфікуючий склад якого належить до групи кримінальних проступків, тобто тяжкість кримінального правопорушення в такому разі однакова. Це випливає з санкції кримінально-правової норми, оскільки за основний склад кримінального правопорушення, передбаченого ч. 1 ст. 125 КК України, встановлено покарання у вигляді штрафу до п'ятдесяти неоподатковуваних мінімумів доходів громадян або громадські роботи на строк до двохсот годин, або випрані роботи на строк до одного року. Що стосується кваліфікованого складу, передбаченого ч. 2 ст. 125 КК України, то за його вчинення передбачено покарання у вигляді штрафу від п'ятдесяти до ста неоподатковуваних мінімумів доходів громадян або громадські роботи на строк від ста п'ятдесяти до двохсот сорока годин, або виправні роботи на строк до одного року, або арешт на строк до шести місяців, або обмеження волі на строк до двох років. Однак законодавець закріпив ст. 122 КК України (умисне середньої тяж- кості тілесне ушкодження), в якій здоров'я особи виступає об'єктом кримінально-правового посягання, як і у ст. 125 КК України. Проте основний і кваліфікований склад умисного середньої тяжкості тілесного ушкодження належить до групи злочинів. Оскільки за основний склад кримінального правопорушення, передбаченого ч. 1 ст. 122 КК України, передбачено покарання у вигляді виправних робіт на строк до двох років або обмеження волі на строк до трьох років, або позбавлення волі на строк до трьох років. Що стосується кваліфікованого складу, передбаченого у ч. 2 ст. 122 КК України, за його вчинення передбачене покарання у вигляді позбавлення волі від трьох до п'яти років. У цьому разі можна побачити, як ознака суспільно небезпечного наслідку впливає на тяжкість кримінального правопорушення, збільшуючи останню.

Також до таких ознак належить форма вини. Це вбачається 3 аналізу основного складу кримінального правопорушення, передбаченого ч. 1 ст. 411 КК України (умисне знищення або пошкодження військового майна) і ч. 1 ст. 412 КК України (необережне знищення або пошкодження військового майна), в яких об'єкт кримінально-протиправного посягання спільний, це порядок здійснення права власності щодо військового майна. Однак умисне знищення або пошкодження військового належить до групи злочинів, оскільки за нього передбачене покарання у вигляді позбавлення волі на строк до трьох років, службове обмеження на строк до двох років або тримання у дисциплінарному батальйоні на той самий строк. Що стосується необережного знищення або пошкодження військового майна, то в такому разі це кримінально-протиправне діяння належить до групи кримінальних проступків, тому що за його вчинення передбачене покарання у вигляді штрафу до п'ятдесяти неоподатковуваних мінімумів доходів громадян або службове обмеження на строк до двох років, або тримання у дисциплінарному батальйоні на строк до одного року. У розглянутому нами випадку об'єкт кримінально-протиправного посягання спільний, однак група кримінального правопорушення різна, отже, завдяки зміні форми вини відбувається зменшення тяжкості кримінального правопорушення законодавцем. Тому форма вини має безпосередній вплив на тяжкість кримінального правопорушення.

Заключною ознакою тяжкості кримінального правопорушення виступає спосіб його вчинення. Це можна побачити під час порівняння ч. 1 ст. 185 КК України (крадіжка) і ч. 1 ст. 186 КК України 
(грабіж). Кримінальна відповідальність у ч. 1 ст. 185 КК України передбачена за таємне викрадення чужого майна. Це є основний склад крадіжки, який належить до групи кримінальних проступків, оскільки законодавець передбачив за нього такий вид покарання: штраф від однієї тисячі до трьох тисяч неоподатковуваних мінімумів доходів громадян або громадські роботи на строк від вісімдесяти до двохсот сорока годин, або виправні роботи на строк до двох років, або арешт на строк до шести місяців, або обмеження волі на строк до п'яти років. Що ж стосується ч. 1 ст. 186 КК України, то в ній встановлена кримінальна відповідальність за відкрите викрадення чужого майна, це основний склад грабежу, який належить до групи злочинів, оскільки законодавець передбачив за нього такий вид покарання: штраф від п'ятдесяти до ста неоподатковуваних мінімумів доходів громадян або громадські роботи на строк від ста двадцяти до двохсот сорока годин, або виправні роботи на строк до двох років, або арешт на строк до шести місяців, або позбавлення волі на строк до чотирьох років. Єдиною відмінністю в порівнюваних нами складах кримінальних правопорушень $€$ лише спосіб вчинення і саме він у цьому разі впливає на тяжкість кримінального правопорушення, що супроводжується зміною групи кримінального правопорушення (з кримінального проступку на злочин).

Повертаючись до кримінального права Республіки Польща, варто наголосити на тому, що домінуючою у науковій доктрині є об'єктивно-суб'єктивна концепція того, які ознаки впливають на тяжкість кримінального правопорушення. У цьому разі йдеться про те, що на тяжкість кримінального правопорушення впливають ознаки, які характеризують елементи складу певного виду кримінального правопорушення [12, с. 81].

Також у КК Республіки Польща законодавець стосовно деяких кримінальних правопорушень передбачив випадки їх меншої тяжкості, не даючи дефініції цього поняття, що спричиняє значні труднощі не лише в оцінці такого виду випадків, але й у визначенні його юридичної сутності. У польській науковій доктрині зазначається, що випадок меншої тяжкості кримінального правопорушення - це конструкція, яка межує з видом кримінального правопорушення і покаранням [5, с. 142]. Полягає вона в певній законодавчій специфіці побудови кримінальноправової норми. До прикладу розглянемо арт. 144 КК Республіки Польща, яка закріплена таким чином:

§ 1. Покликаний проходити військову службу, який не з'являється для проходження иієї служби у визначений час та місие, підлягає покаранню у вигляді позбавлення волі до 3 років.

§ 2. У разі меншої тяжкості правопорушник підлягає покаранню у вигляді штрафу, обмеження волі або позбавлення волі до 1 року.

§ 3. Той, хто не з'являється для проходження служби, що замінює військову службу, за умов, визначених у $\$ 1$, підлягає покаранню у вигляді штрафу або обмеження волі.

У такому разі йдеться про використання законодавцем словосполучення «меншої тяжкості» у диспозиції § 2 вищезгаданого артикля, завдяки чому зменшується ступінь суспільної шкідливості кримінально-протиправного діяння, що можна побачити в аналізі санкції § 1 і 2 артикля 148 КК Республіки Польща. Однак кримінальні правопорушення, передбачені § 1 і 2 артикля 148 КК Республіки Польща, залишаються в межах однієї групи тяжкості кримінального правопорушення, належать до групи кримінальних проступків, що також випливає з аналізу їх санкцій. Проте у більшості інших передбачених законодавцем випадках «меншої тяжкості» кримінального правопорушення завдяки зменшенню ступеня суспільної шкідливості кримінально-протиправного діяння відбувається і зміна його групи тяжкості, це відбувається у тих кримінальних правопорушеннях, де основний склад належить до групи злочинів. До прикладу, кримінальне правопорушення, передбачене арт. 228 § 1 КК Республіки Польща (прийняття у зв'язку 3 виконанням публічної функції фінансової чи особистої переваги або їх обіцянки), належить до групи злочинів, а кримінальне правопорушення, передбачене 228 § КК Республіки Польща (те саме діяння меншої тяжкості), належить до групи кримінальних проступків, що випливає з аналізу їх санкцій.

\section{Висновки}

Отже, дослідивши формальний і матеріальний критерії класифікації кримінальних правопорушень на злочини і кримінальні проступки в межах кримінально-правової системи України та Республіки Польща, необхідно наголосити на тому, що український законодавець не враховує у разі формального поділу кримінальних правопорушень форми вини, на відміну від польського законодавця. Також варто зазначити, що обставини, які впливають на тяжкість кримінального правопорушення в Республіці Польща, і саме поняття тяжкості кримінального правопорушення є практично недослідженими, так само, як і в Україні. Тому запропоновані нами позиції є актуальними для кримінально-правових систем двох держав. 


\section{Список використаних джерел:}

1. Кривоченко Л.Н. Классификация преступлений. Харьков : Вища шк. Изд-во при Харьк. ун-те, 1983. $129 \mathrm{c}$.

2. Кримінальний кодекс України : Закон України від 05.04.2001р. № 2341-III. Відомості Верховної Ради України. 2001. № 25-26. Ст. 131.

3. Про внесення змін до деяких законодавчих актів України щодо спрощення досудового розслідування окремих категорій кримінальних правопорушень : Закон України від 22.11.2018 р. № 2617-VIII. URL: https://zakon.rada.gov.ua/laws/ show/2617-19.

4. Banasik K. Społeczna szkodliwosc czynu. Państwo i Spoleczeństwo, 2005. № 4. S. 87-91.

5. Bojarski T. Odmiany podstawowych typów przestępstw w polskim prawie karnym. Warszawa : Wydaw. Prawnicze, 1982. 215 s.

6. Bojarski T. Polskie prawo karne. Zarys części ogólnej. Wyd. 1. Warszawa: LexisNexis, 2002. 296 s.

7. Buchała K., Zoll A. Kodeks karny. Część ogólna. Komentarz. Kraków : Kantor Wydaw. Zakamycze, 1998. $657 \mathrm{~s}$.

8. Gardocki L. Prawo karne. 20 wydanie. Warszawa : C.H. Beck, 2017. $361 \mathrm{~s}$
9. Góral R. Kodeks karny. Praktyczny komentarz z orzecznictwem. Wyd. 4. Warszawa : Wydaw. Zrzeszenia Prawników Polskich, 2005. 654 s.

10. Jankowska-Prochot I. Definicja przestepstwa i jego klasyfikacja w polskim oraz irlandzkim prawie karnym. Prokuratura i Prawo, 2018. № 10. 29-46 s.

11. Kolendowska-Matejczuk M., Vacher V. Węzłowe problemy prawa wykroczeń. Czy potrzebna jest reforma?. Warszawa : Biuro Rzecznika Praw Obywatelskich, 2016.207 s.

12. Plebanek E. Wypadek mniejszej wagi - kilka uwag na temat charakteru instytucji. Czasopismo Prawa Karnego i Nauk Penalnych, 2011. nr 1. S. 81-98.

13. Postanowienie Sądu Najwyższego z dnia z dnia 13 października 2004 r. V KK 216/04, (LEX nr 126719).

14. Wróbel W. Nowelizacja prawa karnego 2015. Komentarz. Kraków : Krakowski instytut prawa karnego, 2015. $1064 \mathrm{~s}$.

15. Wyrok Sądu Apelacyjnego w Krakowie z 30 marca 2005 r., II AKa 50/05 (KZS 2005, z. 5, poz. 33).

16. Wyrok Sądu Apelacyjnego w Katowicach z dnia 13 stycznia 2005 r., II AKa 455/04 (Prok. Pr. wkł. 2006. Nr 1. poz. 21).

This article is devoted to investigation of criteria for classification of criminal offences into felonies and misdemeanor under criminal law in Ukraine and in Republic of Poland. In the framework of the study were considered the formal and material criteria for the division of criminal offenses, which are distinguished by both Ukrainian and Polish scientists. The formal criterion for the division of criminal offenses into felonies and misdemeanor in the criminal law of the Republic of Poland is determined by certain elements, such as the legal consequence and the condition that is provided by the criminal law. As for the legal consequences, in this case we are talking about the type and measure of punishment provided by the sanctions of the relevant criminal law norm. The legal condition is understood as a form of guilt of a criminal offense, since according to Art. 8 of the Criminal Code of the Republic of Poland a crime may only be committed intentionally, while misdemeanor may be committed both intentionally and through negligence. As for the Ukrainian criminal law, the formal criterion for the division of a criminal offense consists only of a legal consequence, i.e. the type and measure of punishment provided by the sanction of the relevant criminal law norm. This conclusion was made due to the study of the new edition of Article 12 of the Criminal Code of Ukraine, which is proposed by the Law of Ukraine "On Amendments to certain legislative acts of Ukraine regarding the Simplification of the Pre-trial Investigation of Certain Categories of Criminal Offenses” № 2617-VIII from November 22, 2018 , introduction by virtue of which is scheduled for July 1,2020.

As for the material criterion, it consists in the division of criminal offenses into felonies and misdemeanor according to the gravity of the criminal offense, which is determined by the degree of public danger (harmfulness) of the action.

However, in the criminal law doctrine of both Ukraine and the Republic of Poland there is no single approach to interpret these terms.

The circumstances and signs affecting the gravity of the criminal offense, both in Ukraine and in the Republic of Poland, have been investigated.

Key words: formal criterion, material criterion, degree of public danger (harmfulness) of action, gravity of criminal offense, sanction, criminal act. 